\title{
Seasonal vegetative growth of different age branches of conilon coffee tree
}

\section{Crescimento vegetativo sazonal em ramos de diferentes idades do cafeeiro conilon}

\author{
Fábio Luiz Partelli ${ }^{1 *}$, Henrique Duarte Vieira ${ }^{2}$; \\ Marcelo Gabeto Silva ${ }^{3}$; José Cochicho Ramalho ${ }^{4}$
}

\begin{abstract}
The seasonal pattern of vegetative growth is an important feature for evaluation of crop status and its management. The aim of this work was to evaluate the seasonality of vegetative growth of Conilon coffee tree (Coffea canephora Pierre) and its relation with climate variables. The evaluation of vegetative growth rates of three groups of plagiotropic branches and one group of orthotropic branches was performed along one year, in Rio Janeiro state, Brazil. The vegetative growth rates of the branches varied along the period of evaluation, and it seems to be related to the minimum air temperature (in the low growth phase). Higher growth rates were observed when the average of minimum air temperatures was higher than $17^{\circ} \mathrm{C}$ and the average of the maximum temperatures lower than $31.5^{\circ} \mathrm{C}$. Below $17^{\circ} \mathrm{C}$ the growth rate declined. The branches' growth patterns appeared to be similar, but the plagiotropic branches of different ages presented different rates in the same period of the year, indicating that seasonal growth studies should not be based on a single branch group with the same age.
\end{abstract}

Key words: Coffea canephora, air temperature, stress

\section{Resumo}

O padrão do crescimento sazonal do cafeeiro é um importante auxiliar na avaliação do estado fisiológico e no manejo da cultura. O objetivo do estudo foi avaliar o crescimento vegetativo em Coffea canephora Pierre cv. Conilon e relacionar com fatores climáticos, tendo por base o crescimento de ramos ortotrópicos e plagiotrópicos com diferentes idades. Marcaram-se três grupos de ramos plagiotrópicos e um de ramos ortotrópicos, cuja avaliação de taxa de crescimento foi efetuada durante um ano no Estado do Rio de Janeiro. A taxa de crescimento varia ao longo do ano, o que parece estar relacionado com a temperatura mínima do ar (na fase de baixo crescimento). Foi observada taxa mais elevada quando a média da temperatura mínima do ar foi superior a $17^{\circ} \mathrm{C}$ e a média das temperaturas máximas inferior a $31,5^{\circ} \mathrm{C}$. Abaixo de $17^{\circ} \mathrm{C}$ a taxa de crescimento dos ramos diminuiu. O padrão sazonal de crescimento dos ramos é semelhante, contudo, os ramos plagiotrópicos de diferentes idades apresentam taxas de crescimento diferentes no mesmo período do ano. Assim, estudos sobre o crescimento vegetativo sazonal dos ramos não deve se basear apenas num grupo de ramos com idades similares.

Palavras-chave: Coffea canephora Pierre, temperatura do ar, estresse

\footnotetext{
${ }^{1}$ Engenheiro Agrônomo, Doutor em Produção Vegetal. Professor da Universidade Federal do Espírito Santo, Centro Universitário Norte do Espírito Santo. Departamento de Ciências Agrárias e Biológicas. Rodovia BR 101 Norte, Km. 60, Bairro Litorâneo., 29932-540, São Mateus, ES. E-mail: partelli@yahoo.com.br

${ }^{2}$ Engenheiro Agrônomo, Doutor e Professor da Universidade Estadual do Norte Fluminense Darcy Ribeiro. E-mail. henrique@ uenf.br

${ }^{3}$ Engenheiro Agrônomo, Doutor. Instituto de Defesa Agropecuária e Florestal do Espírito Santo. E-mail: mgabettosilva@gmail.com

${ }^{4}$ Biólogo, Doutor e Pesquisador do Instituo de Investigação Científica Tropical, Centro Eco-Bio. E-mail: cochichor@mail.telepac.pt

* Autor para correspondência
} 


\section{Introduction}

The genus Coffea comprehends at least 103 species, with commercial relevance for $C$. arabica and C. canephora (DAVIS et al., 2006). World's coffee production in the last years has being of more than 110 million sacks, produced essentially in developing countries (ICO, 2009). Brazil is the world's biggest coffee producer and exporter, and it has in this crop an important source of incomes, employment and local development in the producing or processing regions. During the 2008 period, Brazilian production of C. arabica was of 35.5 millions of sacks (of $60 \mathrm{~kg}$ ) and 10.5 million of C. canephora, in a 2.36 million hectares area, with 5.81 billions coffee plants (CONAB, 2009).

The seasonal growth fluctuations in coffee plants have been studied in some producing regions. It has been observed that for latitudes higher than $15{ }^{\circ} \mathrm{S}$, the greatest vegetative growth occurs with longer and warmer days, as well as with higher precipitation, whereas the lower vegetative growth rates were observed in the colder months with shorter days (BARROS et al., 1997; LIBARDI; AMARAL; AMARAL, 1998; NAZARENO et al., 2003; SILVA et al., 2004). Such decay in the growth rate is not related to photoperiod (MOTA et al., 1997; AMARAL; RENA; AMARAL, 2006) or with the presence of fruits in the branches, although the branches without fruits may present higher rates (LIBARDI; AMARAL; AMARAL, 1998; AMARAL; RENA; AMARAL, 2006). It has been reported that the $C$. arabica low growth phase seems to occur at field temperatures lower than $14^{\circ} \mathrm{C}$ (AMARAL; RENA; AMARAL, 2006), which could be related to minimum air temperatures. However, C. canephora is usually more sensitive to low temperatures, what is probably related with its evolution ecological conditions in the low lands of the African continent (RENA; MAESTRI, 1986; DAVIS et al., 2006).

In many plants low positive temperatures affects several components of the photosynthetic machinery, leading to a reduction in stomatal conductance, net photosynthesis, the photochemical efficiency of photosystem II, thylakoid electron transport, the activity of carbon metabolism enzymes, as well as promoting changes in the structure and composition of photosynthetic pigment complexes, as observed in $C$. arabica and C. canephora plants (CAMPOS et al., 2003; RAMALHO et al., 2003; SILVA et al., 2004; PARTELLI et al., 2009; 2010).

Understanding seasonal vegetative growth characteristics in C. canephora Pierre cv. Conilon is an important tool for the evaluation of the plant physiological status, with implications for crop management. Despite this, minor attention has been paid to branch growth characteristics in cv. Conilon in Brazil. The present study therefore investigates how climatic variables impact on vegetative growth seasonality in branches with different ages in $C$. canephora cv. Conilon.

\section{Material and Methods}

This assay was performed in the district of Campos dos Goytacazes in Rio de Janeiro state, Brazil, with an altitude $c a .11 \mathrm{~m}$, at $21^{\circ} 45^{\prime} \mathrm{S}$ and $41^{\circ} 20^{\prime} \mathrm{W}$, using 4 year old C. Canephora Pierre cv. Conilon plants. These were cultivated in an Entisols soil type under total Sun exposure conditions, $2.5 \mathrm{x}$ $1 \mathrm{~m}$ apart.

Elongation measurements of new branches (with about $8 \mathrm{~cm}$ and 2 pairs of leaves) were performed every 15 days beginning (after fruit yield) on $28 / 07 / 2003$ using 20 orthotropic branches selected in the upper part of 20 different plants (one branch per plant), as well as in 20 randomly chosen plagiotropic branches ( $1^{\text {st }}$ group). Other 2 sets of 20 plagiotropic branches were analyzed from $14 / 11 / 2003\left(2^{\text {nd }}\right.$ group) and 17/03/2004 ( $3^{\text {rd }}$ group). The branches were followed continuously until 27/07/2004.

Some environmental data (air temperature and relative humidity, precipitation and irradiation) and total evapotranspiration $\left(\mathrm{ET}_{\mathrm{o}}\right)$ were collected in 
a weather station (model Thies Clima, Germany), located at the experimental site. The data presented are means of 15 days' intervals.

Statistical analysis of growth data included a two-way ANOVA $(\mathrm{P}=0.05)$ to study the evolution of growth for each branch type along the year and to compare the several branch types at each date. Differences in growth rates within and between the several branch groups were also tested for over one year using the Tukey test (for 95\% confidence). Environmental data was used for the establishment of some correlations with the growth evolution.

\section{Results and Discussion}

From $1 / 05$ to $27 / 07 / 2004$, the $2^{\text {nd }}$ and $3^{\text {rd }}$ plagiotropic branch groups presented a decrease in the growth rate (Figure 1), which could be associated to the occurrence of low minimum temperatures (Figure 2A), despite the fact that the mean temperature has been considerate adequate for growth (RENA; MAESTRI, 1986). Such a reduction was clearer when the average minimum temperature was below $17^{\circ} \mathrm{C}$, as observed in the period between 28/07 and 28/08/2003 ( $1^{\text {st }}$ group of plagiotropic and orthotropic branches) and between $2 / 06$ and 27/07/2004 ( $2^{\text {nd }}$ and $3^{\text {rd }}$ group of plagiotropic and orthotropic branches), when the temperature reached $14.8{ }^{\circ} \mathrm{C}$ (from 13 to $28 / 08 / 2003$ ) and several registered daily values were around $13.5^{\circ} \mathrm{C}$. These results are in agreement with other reports of a coincidence of minimal growth rates in Conilon Coffee between May and August with the year lower temperatures (LIBARDI; AMARAL; AMARAL, 1998). That would be related to the strong negative impact on the photosynthetic metabolism and structures, including the photoprotective pigments, when exposed to low temperatures, leading to strong post effects even when temperatures rise again (RAMALHO et al., 2003; PARTELLI et al., 2009; 2010).

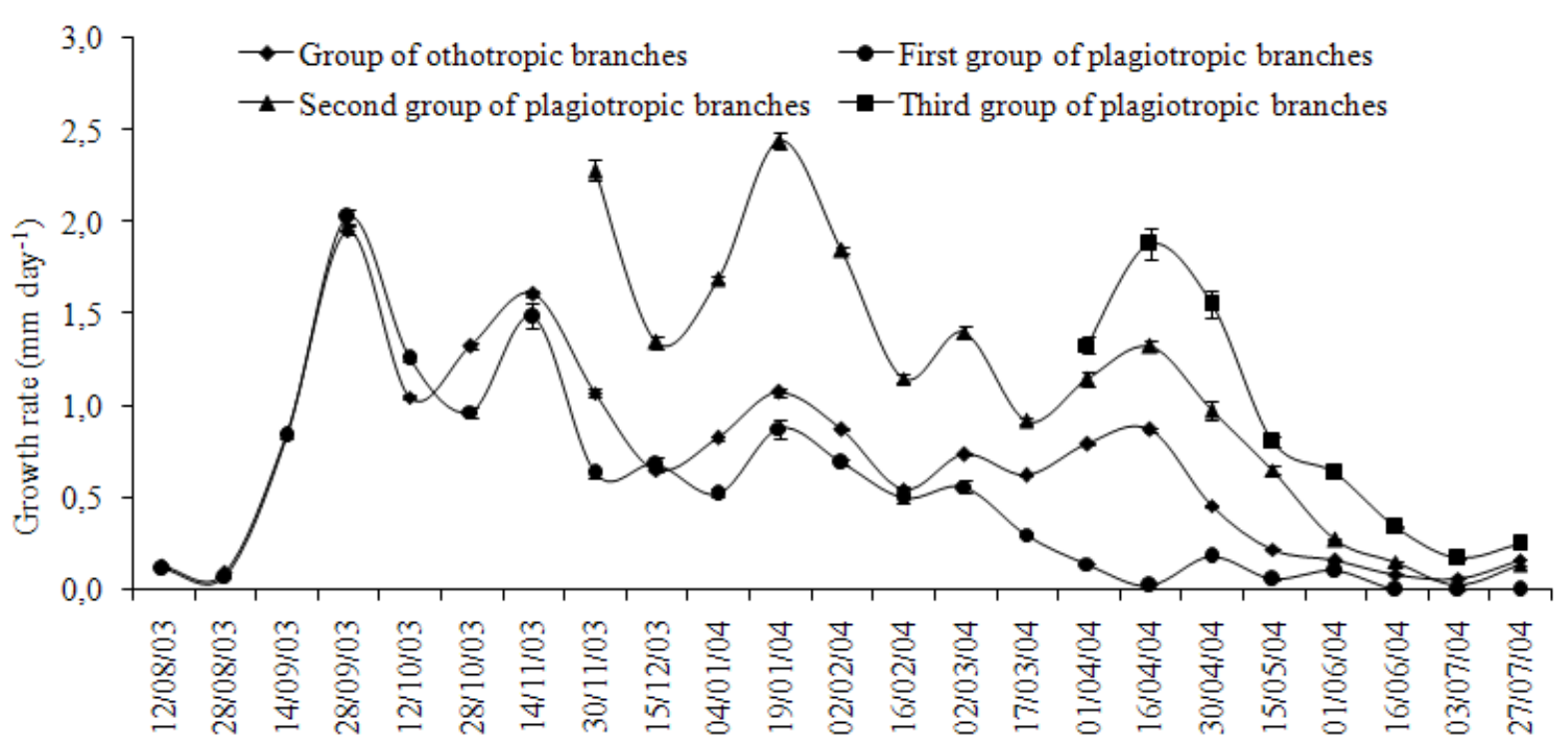

Periods

Figure 1. Vegetative growth rate $\left(\mathrm{mm} \mathrm{day}^{-1}\right)$ in the 3 groups of plagiotropic branches with different ages and in the group of orthotropic branches of $C$. canephora cv. Conilon, along one year under field conditions. The values represent the average \pm SE $(n=20)$ for a period of about 15 days. 


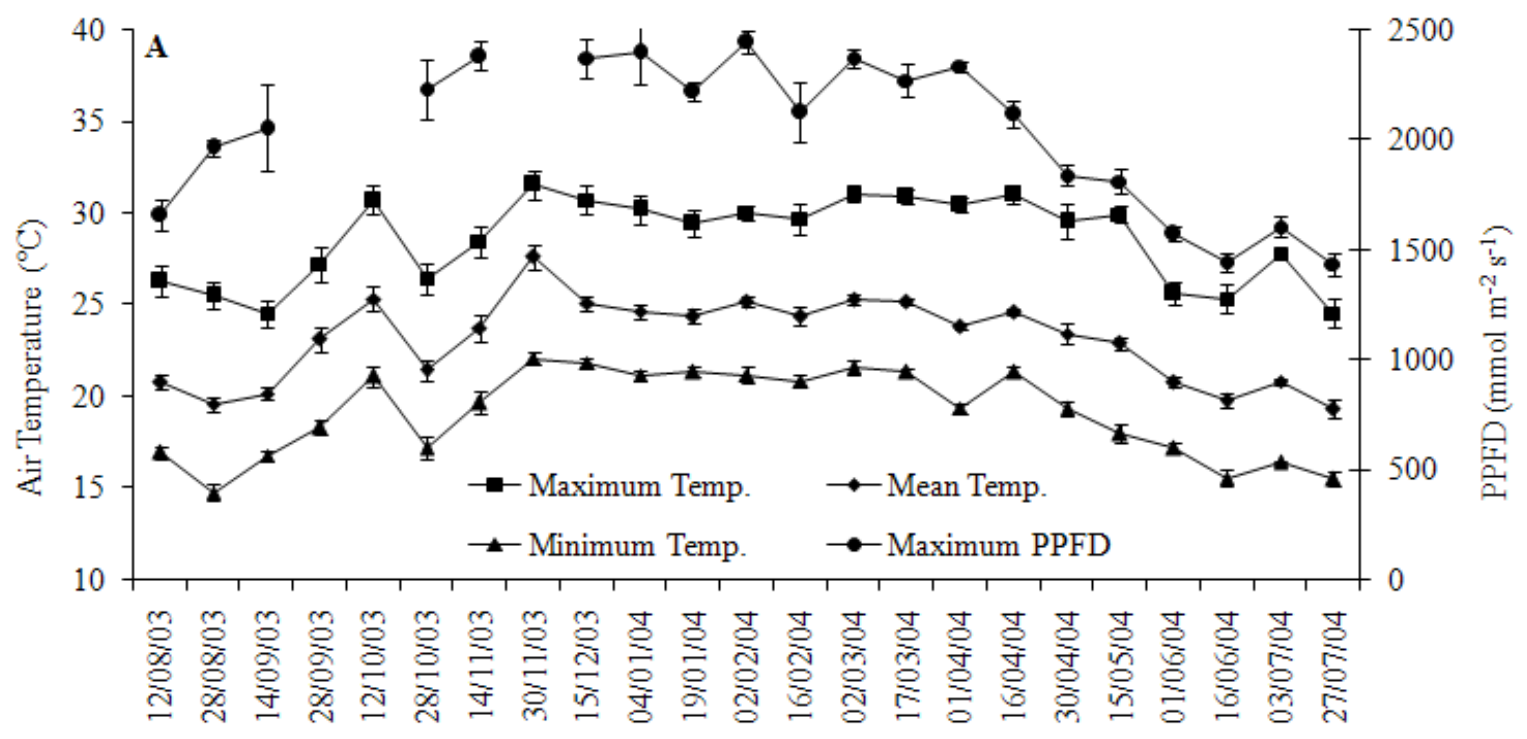

Periods

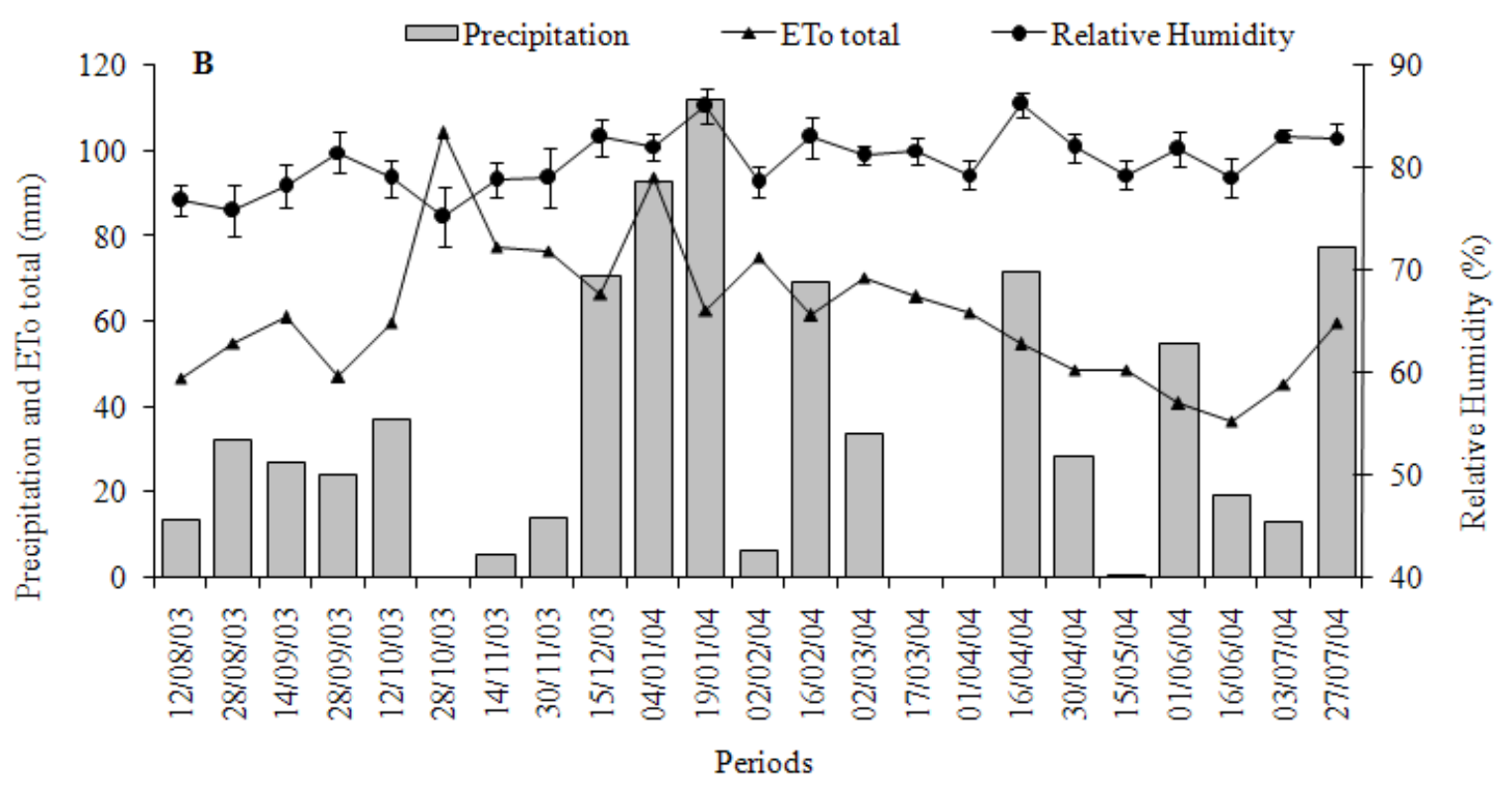

Figure 2. Variation of the irradiation (PPFD), minimum, mean and maximum temperatures (A); variation of the precipitation, total evapotranspiration (ETo) and air relative humidity (B), along the experiment. The values represent the average $\pm \mathrm{SE}(\mathrm{n}=15$ days). 
Notably, some decrease of the growth rate was also observed between 30/11/2003 and 4/01/2004, what could not be attributed to low temperature conditions. Instead, it would probably have relation with some water shortage observed in part of this period of the year (Figure 2B).

The regressions between branch growth and all environmental parameters were non-significant when the entire time period of the experiment was considered. Similar results were obtained when the high growth phase was considered (data not shown). However, a more detailed study, considering only the period of temperature decrease, showed significant correlations. The best fit were obtained using the average of minimum temperatures, with $r^{2}=0.821$ for orthotropic branches and $r^{2}=0.922$ and 0.941 for the $2^{\text {nd }}$ and $3^{\text {rd }}$ group of plagiotropic branches (Figure 3).

Only for the oldest group of plagiotropic branches (the $1^{\text {st }}$ ) showed no significant correlation, which can be attributed to the fact that the growth rate decrease even under good temperature conditions, was virtually null by the end of the measurement period. This could be related to the significant reductions in the photosynthetic metabolism, as was observed in $C$. canephora cv. Apoatã for temperatures lower than $20 / 15^{\circ} \mathrm{C}$ (day/night) (RAMALHO et al., 2003). However, possible effects of competition exerted by grain formation and maturation, and by the induction and maturation of flower gems, should not be excluded, since these are important temporary nutrient sinks (MALAVOLTA et al., 2002).

The branch growth rate (Figure 1) was higher in the warmer months, from September to May (Figure $2 \mathrm{~A}$ ), when the temperatures values were higher than $17^{\circ} \mathrm{C}$ (minimal) and lower than $31.5^{\circ} \mathrm{C}$ (maximal), which agrees with Libardi, Amaral e Amaral, (1998) who indicate the beginning of growth stage for cv. Conilon is September in the Espírito Santo state, Brazil. In the same period, the mean temperature varied between 21 and $27.5^{\circ} \mathrm{C}$, which compares well with the mean values between 22 and $26^{\circ} \mathrm{C}$ reported by RENA and MAESTRI (1986) considered suitable temperatures for vegetative development in cv. Conilon.
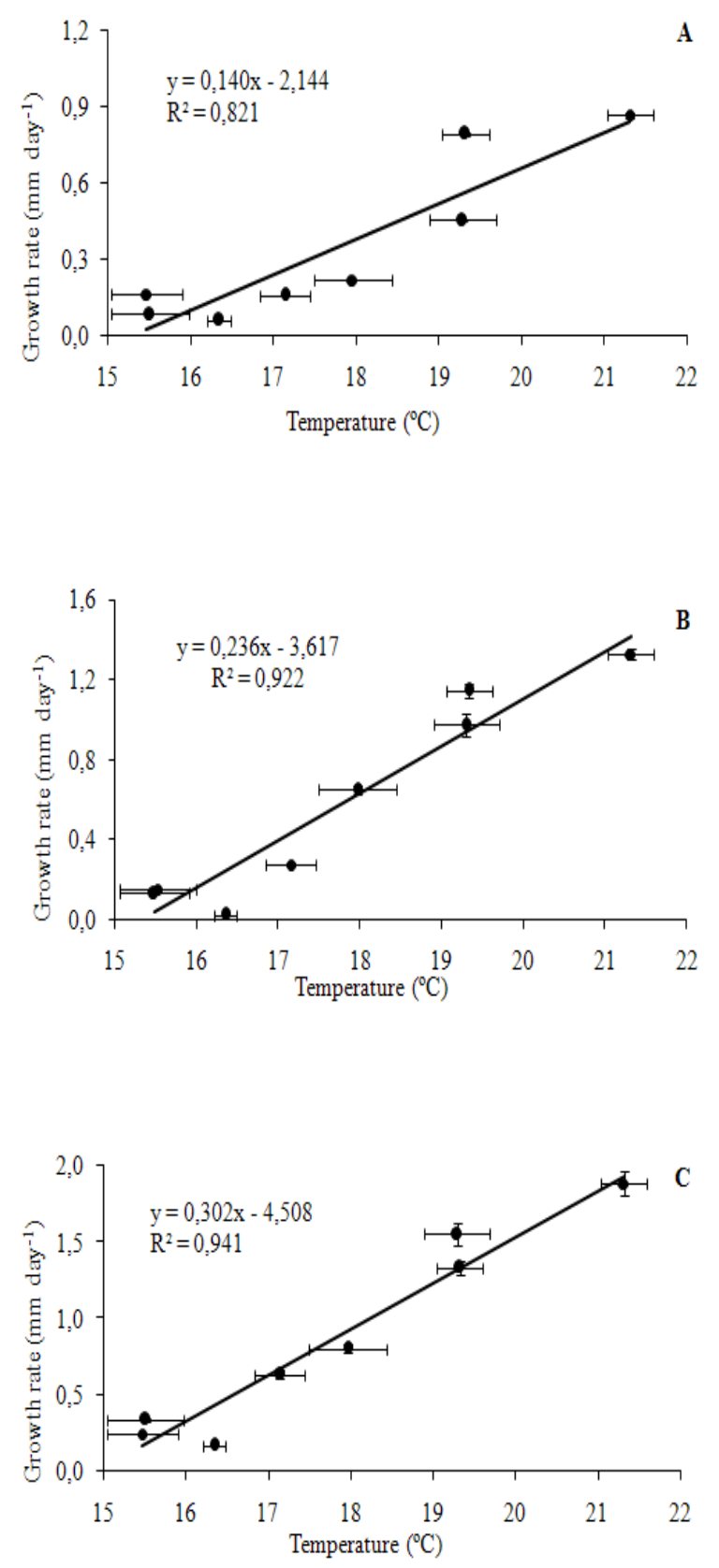

Figure 3. Regressions between the average of minimum temperatures (taken between 18/03 and 27/07/2004) and the vegetative growth rate of the orthotropic branches (A), as well as with the $2^{\text {nd }}(B)$ and $3^{\text {rd }}(C)$ groups of plagiotropic branches. 
Despite some differences in the absolute growth rates, the growth pattern of the plagiotropic branches is quite similar (Figure 1). At a young phase, they present higher growth. On the other hand, at $7^{\text {th }}$ months of age (18/03/2004) the $1^{\text {st }}$ group presented a growth. This seems to be related to a reduction in vigour, but not to temperature, since by that time the other plagiotropic branches presented increased growth rates. In this way, the study of branch growth should include branches of different ages, selected along the year.

Branch vegetative growth in cv. Conilon did not present significant correlations with the variations in air RH, probably because the values were always quite high, or with the average of maximal irradiance levels, which reached values above $2000 \mu \mathrm{mol} \mathrm{m}{ }^{-2}$ $\mathrm{s}^{-1}$ in most of the 15 day periods studied (Figure 2).

Hot season some periods of lower growth seems to accompany a decrease in water availability due to low precipitation values (Figure 2A). For instance, between $4 / 10$ and 9/11 the plants did not receive any water supply, which provoked a generalized wilting of leaves (personal observation in the field), concomitant with a decrease in the branch growth. By 10/11 the crop was irrigated and a rise in the growth rate was observed. In fact, it is known that $C$. canephora cv. Conilon plants under drought suffer severe decreases in the assimilation rate (DAMATTA et al., 2002; LIMA et al., 2002; PINHEIRO et al., 2004; PRAXEDES et al., 2006).

\section{Conclusion}

Branch growth display changes due to branch age and along the year, with the minimum temperature having a significant role in such seasonal behaviour growth. On the other hand, high vegetative growth rates are observed in C. canephora cv. Conilon when the average temperature was $21-27.5^{\circ} \mathrm{C}$, except when water availability decreases.

This also indicates that studies of seasonal growth patterns should not be based on a single branch group with the same age, due to a gradual loss of vigour that limits growth.

\section{References}

AMARAL, J. A. T.; RENA, A. B.; AMARAL, J. F. T. Crescimento vegetativo sazonal do cafeeiro e sua relação com fotoperíodo, frutificação, resistência estomática e fotossíntese. Pesquisa Agropecuária Brasileira, Brasília, v. 41, n. 3, p. 377-384, 2006.

BARROS, R. S.; MOTA, J. W. S.; DAMATTA, F. M.; MAESTRI, M. Decline of vegetative growth in Coffea arabica $\mathrm{L}$. in relation to leaf temperature, water potential and stomatal conductance. Field Crops Research, Warwick, v. 54, n. 1, p. 65-72, 1997.

CAMPOS, P. S.; QUARTIN, V.; RAMALHO, J. C.; NUNES, M. A. Electrolyte leakage and lipid degradation account for cold sensitivity in leaves of Coffea sp. plants. Journal of Plant Physiology, Leipzig, v. 160, n. 3, p. 283292, 2003.

COMPANHIA NACIONAL DE ABASTECIMENTO - CONAB. Acompanhamento da safra Brasileira: café safra 2009 segunda estimativa. Avaliable via dialog: $<$ http://www.conab.gov.br/conabweb/download/ safra/ 2cafe_09.pdf $>$. Accessed: 31 August 2009.

DAMATTA, F. M.; LOOS, R. A.; SILVA, E. A.; LOUREIRO, M. E. Limitation to photosynthesis in Coffea canephora as a result of nitrogen and water availability. Journal of Plant Physiology, Leipzig, v. 159, n. 9, p. 975-981, 2002.

DAVIS, A. P.; GOVAERTS, R.; BRIDSON, D. M.; STOFFELEN, P. An annotated taxonomic conspectus of the genus Coffea (Rubiaceae). Botanical Journal of the Linnean Society, Londres, v. 152, n. 4, p. 465-512, 2006.

ICO. International Coffee Organization. Trade statistics. Avaliable via dialog: $<$ http://www.ico.org/coffee_prices. asp>. Accessed: 31 Aug. 2009.

LIBARDI, V. C. M.; AMARAL, J. A. T.; AMARAL, J. F. T. Crescimento vegetativo sazonal do cafeeiro (Coffea canephora Pierre var. Conilon) no sul do Estado do Espírito Santo. Revista Brasileira de Agrometeorologia, Piracicaba, v. 6, n. 1, p. 23-28, 1998.

LIMA, A. L. S.; DAMATTA, F. M.; PINHEIRO, A. H.; TOTOLA, M. R.; LOUREIRO, M. E. Photochemical responses and oxidative stress in two clones of Coffea canephora under water deficit conditions. Environmental and Experimental Botany, Paris, v. 47, n. 3, p. 239-247, 2002. 
MALAVOLTA. E.; FAVARIN, J. L.; MALAVOLTA, M.; CABRAL, C. P.; HEINRICHS, R.; SILVEIRA, J. S. M. Repartição de nutrientes nos ramos, folhas e flores do cafeeiro. Pesquisa Agropecuária Brasileira, Brasília, v. 37, n. 9, p. 1017-1022, 2002.

MOTA, J. W. S.; DAMATA, F. M.; BARROS, R. S.; MAESTRI, M. Vegetative growth in Coffea arabica L. as affected by irrigation, daylength and fruiting. Tropical Ecology, Varanasi, v. 38, n. 1, p. 73-79, 1997.

NAZARENO, R. B.; OLIVEIRA, C. A. S.; SANZONOWICZ, C.; SAMPAIO, J. B. R.; SILVA, J. C. P.; GUERRA, A. F. Crescimento inicial do cafeeiro Rubi em respostas a doses de nitrogênio fósforo e potássio e a regime hídricos. Pesquisa Agropecuária Brasileira, Brasília, v. 38, n. 8, p. 903-910, 2003.

PARTELLI, F. L.; VIEIRA, H. D.; VIANA, A. P.; BATISTA-SANTOS, P.; RODRIGUES, A. P.; LEITÃO, A. E.; RAMALHO, J. C. Low temperature impact on photosynthetic parameters of coffee genotypes. Pesquisa Agropecuária Brasileira, Brasília, v. 44, n. 11, p. 1404$1415,2009$.

PARTELLI, F. L.; VIEIRA, H. D.; RODRIGUES, A. P. D.; PAIS, I.; CAMPOSTRINI, E., CHAVES, M. M. C. C.; RAMALHO, J. C. Cold induced changes on sugar contents and respiratory enzyme activities in coffee genotypes. Ciência Rural, Santa Maria, v. 40, n. 4, p. 781-786, 2010.
PINHEIRO, A. H.; DAMATTA, F. M.; CHAVES, A. R. M.; FONTES, E. P. B.; LOUREIRO, M. E. Drought tolerance in relation to protection against oxidative stress in clones of Coffea canephora subjected to long-term drought. Plant Science, Davis, v. 167, n. 6, p. 1307-1314, 2004.

PRAXEDES, S. C.; DAMATTA, F. M.; LOUREIRO, M. E.; FERRÃO, M. A. G.; CORDEIRO, A. T. Effects of long-term soil drought on photosynthesis and carbohydrate metabolism in mature robusta coffee (Coffea canephora Pierre var. kouillou) leaves. Environmental and Experimental Botany, Paris, v. 56, n. 3, p. 263-273, 2006.

RAMALHO, J. C.; QUARTIN, V. L.; LEITÃO, E.; CAMPOS, P. S.; CARELLI, M. L. C.; FAHL, J. I.; NUNES, M. A. Cold Acclimation Ability and Photosynthesis among Species of the Tropical Coffea Genus. Plant Biology, Freiburg, v. 5, n. 11, p. 631-641, 2003.

RENA, A. B.; MAESTRI, M. Fisiologia do Cafeeiro. In: RENA, A. B.; MALAVOLTA, E.; ROCHA, M.; YAMADA, T. (Ed.). Cultura do cafeeiro: fatores que afetam a produtividade. Piracicaba: PATAFOS, 1986. p. 13-85.

SILVA, E. A.; DAMATTA, F. M.; DUCATTI, C.; REGAZZI, A. J.; BARROS, R. S. Seasonal changes in vegetative growth and photosynthesis of Arabica coffee trees. Field Crops Research, Warwick, v. 89, n. 2-3, p. 349-357, 2004 
